\title{
ENERGY CONFRONTATION OF UKRAINE AND RUSSIA IN THE FRAMEWORK OF HYBRID WAR
}

\begin{abstract}
The specific use of the "energy weapon" in the hybrid war is being analyzed. The author highlights the historical retrospective use of the "energy weapon" in general and against Ukraine in particular. Now the energy component of hybrid war is the second in importance and power after the information component. The main political task of the gas conflict between Moscow and Kyiv, which was inspired by the Kremlin, was to demonstrate the inability of Ukraine as a transit partner and to damage the reputation of our country as a reliable transit, geoeconomic and geopolitical partner of the European Union. During the gas conflict Russia tried to position itself as an influential geopolitical player to preserve Ukraine in its sphere of political influence. By blackmail and promises to keep "special conditions" in the price formation Kremlin sought to protect its geopolitical interests in Ukraine. Upon solving the gas conflict, Moscow has tried to block the implementation of the provisions of the Charter on Strategic Partnership between Ukraine and the United States on modernization. The "gas weapon" was used for the first time during the winter of 2005-2006. The first gas war demonstrated the vulnerability of Ukraine and European consumers, and demonstrated how effective and promising may be the further use of energy weapons.

Gas weapons are used on several different fronts. First, Russia claims Ukraine is not trustworthy as a transit country for gas as it will act firstly to protect its own interests. In other words, Gazprom offers Europe a choice - or they, European consumers and voters, suffer or Ukraine does. Second, Russian specialists are ready at the first opportunity to accuse Ukraine of unsanctioned gas use, thereby justifying a reduction in supply to Europe. Third, Gazprom intends to prevent establishing reserve gas supplies in Ukraine. Fourth, Russia views Ukrainian gas debts as a source of financial income particularly necessary today.
\end{abstract}

* Yevhen Magda, National Technical University of Ukraine "Kyiv Polytechnic Institute”, Publishing and Printing Institute. e-mail: rozumaha@gmail.com. 